\title{
Editorial Vol. 74(2) June 2021
}

B. N. Chakraborty ${ }^{1,2}$

C Indian Phytopathological Society 2021

Dear Readers,

The second issue, volume 74 of Indian Phytopathology for April-June 2021 is a special issue on "Phytopathology in Achieving UN Sustainable Development Goals". In fact, during 2020 being International year of Plant Health as declared by United Nations General Assembly, Indian Phytopathological Society (IPS) organized 7th International Conference on "Phytopathology in Achieving UN Sustainable Development Goals" in collaboration with International Society of Plant Pathology (ISPP) along with 12 most prominent plant protection societies within and outside the country. This conference provided a global platform where the galaxy of learned delegates from worldwide conversed the issues concerning the pertinent goals. Contributions by the world scientific communities from USA, China, Australia, Hungary, Nigeria, Iran and India in the form of review and research articles in this special issue have been included as useful document for future initiatives in the improvement of crop health in particular and in enhancing crop productivity in general. In this issue there are twenty three invited articles which includes twenty review articles and three research articles.

When we look at the United Nations Sustainable Development Goals, we see 17 objectives against which we must measure our progress. We know that inclusive and sustainable growth are imperative for the wealth of our planet and for continued success of our enterprises. Global agriculture has been threatened by plant diseases and crop losses and these are the major constraint in achieving the targeted productivity of crop plants globally. The Science of Phytopathology is exceedingly important for crop security.

B. N. Chakraborty

bncnbu@gmail.com

Indian Phytopathological Society, New Delhi, India

2 Department of Biological Sciences, Aliah University, Kolkata, India
The agricultural community is confronted with dual challenges; increasing production of nutritionally dense food and decreasing the impacts of these crop production systems on the land, water, and climate. Dr. Daniel P. Roberts and his group in the first review article on "Precision agriculture and geospatial techniques for sustainable disease control" have emphasized on geospatial tools being developed to aid the farmer in managing cropping system and disease management strategies that are more sustainable but increasingly complex. Geoinformatics and cloud-based, big datadriven applications have also been discussed to speed up crop germplasm improvement as well as crop tolerance to biotic and abiotic stresses under different cropping systems and environmental conditions. Plant pathogen detection and disease diagnosis is the first step in disease management which is necessary for sustaining optimum yield of economically important crops. Dr. B. N. Chakraborty and Dr. U. Chakraborty have highlighted serological and molecular techniques available for detection of fungal pathogens in plants, followed by management practices using bioinoculants which can induce immunity in plants. Bacterial blight caused by Xanthomonas oryzae pv. oryzae (Xoo) is an important productivity limiting factor for rice growers globally. To ensure its nutritional requirement during colonization and multiplication, particularly in the nutrient-depleted intercellular spaces, Xoo targets rice SWEET proteins belonging to sugar transporter family. Dr. Kalyan K Mandal and his group have presented a comprehensive review on rice SWEET proteins and their regulation via Xoo TALEs during bacterial blight development which will be helpful to formulate strategies towards developing resistance to bacterial blight pathogen.

Dr. Apurba K. Chowdhury has summarized current status of knowledge on the two important and threatening wheat diseases-spot blotch and blast, their impact on crop loss, epidemiological conditions for disease development and breeding for disease resistance of both diseases. Extensive research work on genetics, use of molecular markers, cloning and characterization of genes for spot blotch resistance and monitoring of wheat blast disease, improvement of genetic 
resistance as well as development of predictive model has also been suggested. Dr. M. S. Saharan and his group presented an overview on pathogenic and genetic variability and sources of resistance of Fusarium head blight (FHB) of wheat in India. Development of FHB resistant cultivars will lead to reduction in the mycotoxin in harvested grain and help in facilitating export of wheat. Immunity is an innate quality of wheat to avoid rust diseases. Dr. S. C. Bhardwaj has explained the theory, fact and practice of immunity to rust in wheat with special reference to non-host resistance through genetic changes in virulence which emphasizes the role of modern tools and novel principles in the management of wheat rust through durable resistance. Marker assisted breeding for rust management in wheat has also been discussed by Dr. N. Mallick and her investigating group.

Sesame phyllody, brinjal little leaf, sugarcane grassy shoot, sandal spike, coconut root wilt, areca nut yellow leaf and many ornamentals and vegetables maladies are the major phytoplasma threats in India causing serious economic losses every year. An updated status of progress made on different aspects of research on phytoplasma diseases in India have been discussed by Dr. Govind Pratap Rao. Pros and cons for the use of Trichoderma as beneficial organism in agroecosystems has been emphasized by Dr. Laszlo Kredics and his investigating group.The aspects and prospects related to biodiversity, taxonomy and plant disease diagnostics of plant pathogenic fungi from India have been highlighted by Dr. C. Manoharachary and Dr. N. Desaboina. Diversity of Indian isolates of Ralstonia solanacearum inciting bacterial wilt of tomato have been characterized by Dr Dinesh Singh and his coworkers. Advanced molecular diagnostics for detection of plant pathogenic bacteria have been explained by Dr. S. Umesha and Raghava. Epidemiology and prediction models for the management of Alternaria blight, White rust, Downy mildew, Powdery mildew and White stem rot diseases of rapeseed-mustard have been described by Dr. Naresh Mehta. Trichoderma spp. in the management of biotic and abiotic stresses in plants as well as on rural prosperity have been presented by Dr. R. N. Pandey and his investigating group. Scenarios for sustainable management of plant parasitic nematodes have been documented by Dr. B. B. Westerdahl. Ecofriendly management of plant diseases in Sub-Saharan Africa have been focussed by Dr. D. B. Olufolaji and Dr. A. M. Ajayi. Crop disease management strategies for rainfed cropping systems under changing climate scenarios have been reported by Dr. Suseelendra Desai and his group. Plant quarantine for biosecurity during transboundary movement of plant genetic resources have been explained by Dr S. Dubey and his group. Dr. S. M. Paulkhurana and Dr. N. Kumar have pointed out that agricultural sustainability can be ensured by adopting dynamic plant pathology pedagogy. Innovative approaches for Human resource development in fields like agricultural sector and plant pathology in particular have been discussed by Dr. C. Manoharachary.

Dr. R. Viswanathan and his investigating group have identified antifungal nature of 3-deoxy anthocyanidin compounds, apigeninidin and luteolinidin along with differential expression of transcripts involved in the phytoalexin biosynthesis pathway of sugarcane triggered by Colletotrichum falcatum. Dr. A. N. Mishra and his investigating group have evaluated leaf tip necrosis (LTN) associated pleiotropic adult plant resistance (PAPR) genes for wheat rusts. Dr. R. Khangura and Dr. A. J.van Burgel have reported that foliar fungicides and their optimum timing reduced sclerotinia stem rot incidence of Canola which can improve yield.

Contributors, guest editors, reviewers, editorial board members, executive council members of Indian Phytopathological Society and business manager who have put in lot of efforts to bring out this special issue are gratefully acknowledged.

Prof. B. N. Chakraborty

Chief Editor, Indian Phytopathology

Publisher's Note Springer Nature remains neutral with regard to jurisdictional claims in published maps and institutional affiliations. 